\title{
Anticancer Activity and Mechanism of Xanthohumol: A Prenylated Flavonoid From Hops (Humulus lupulus L.)
}

\author{
Chuan-Hao Jiang ${ }^{1 \dagger}$, Tao-Li Sun ${ }^{2+}$, Da-Xiong Xiang ${ }^{3,4,5}$, Shan-Shan Wei, ${ }^{3,4}$ and \\ Wen-Qun Li3,4,5*
}

${ }^{1}$ Department of Laboratory Medicine, The Second Xiangya Hospital, Central South University, Changsha, China, ${ }^{2}$ Key Laboratory Breeding Base of Hu'nan Oriented Fundamental and Applied Research of Innovative Pharmaceutics, College of Pharmacy, Changsha Medical University, Changsha, China, ${ }^{3}$ Department of Pharmacy, The Second Xiangya Hospital, Central South University, Changsha, China, ${ }^{4}$ Institute of Clinical Pharmacy, Central South University, Changsha, China, ${ }^{5}$ Hunan Provincial Engineering Research Center of Translational Medicine and Innovative Drug, Changsha, China

OPEN ACCESS

Edited by:

Luc Pieters,

University of Antwerp, Belgium

Reviewed by:

Andrzej Stepulak,

Medical University of Lublin, Poland

Paula Branquinho Andrade,

Universidade do Porto, Portugal

Agnieszka Barbara Najda,

University of Life Sciences in Lublin,

Poland

Lyndy Joy McGaw,

University of Pretoria, South Africa

*Correspondence:

Wen-Qun Li

liwq1204@csu.edu.cn

tThese authors have contributed equally to this work.

Specialty section:

This article was submitted to Ethnopharmacology, a section of the journal

Frontiers in Pharmacology

Received: 16 February 2018 Accepted: 02 May 2018

Published: 22 May 2018

Citation:

Jiang $C-H$, Sun $T-L$, Xiang $D-X$,

Wei S-S and Li W-Q (2018)

Anticancer Activity and Mechanism

of Xanthohumol: A Prenylated

Flavonoid From Hops (Humulus

lupulus L.). Front. Pharmacol. 9:530.

doi: 10.3389/fphar.2018.00530
It has been observed that many phytochemicals, frequently present in foods or beverages, show potent chemopreventive or therapeutic properties that selectively affect cancer cells. Numerous studies have demonstrated the anticancer activity of xanthohumol $(\mathrm{Xn})$, a prenylated flavonoid isolated from hops (Humulus lupulus L.), with a concentration up to $0.96 \mathrm{mg} / \mathrm{L}$ in beer. This review aims to summarize the existing studies focusing on the anticancer activity of $\mathrm{Xn}$ and its effects on key signaling molecules. Furthermore, the limitations of current studies and challenges for the clinical use of $\mathrm{Xn}$ are discussed.

Keywords: xanthohumol, hops, phytochemical, anticancer, molecular mechanism

\section{INTRODUCTION}

Hops (Humulus lupulus L.), a principal raw material of beer, have been widely used throughout the world in the brewing industry. It acts as a preservative to gives beer the unique aroma and flavor (McAdam et al., 2013; Dostalek et al., 2017). In addition, hops have been used as a medicinal plant for a long history owing to its richness in a variety of phenolic compounds (Zanoli and Zavatti, 2008). The dried hops contain 4-14\% polyphenols, mainly phenolic acids, prenylated chalcones, flavonoids, catechins, and proanthocyanidins (Nikolic and van Breemen, 2013). Xanthohumol (Xn; 3'-[3,3-dimethylallyl]-2', $4^{\prime}, 4$-trihydroxy-6' -methoxychalcone), the most abundant prenylated flavonoid with $0.1-1 \%$ of dry weight in hops, can be isolated from the female inflorescences as shown in Figure 1. It is also a constituent of beer, a major dietary source of prenylated flavonoids, where it has been found at concentrations up to $0.96 \mathrm{mg} / \mathrm{L}(1.95 \mu \mathrm{M})$ (Chen et al., 2012).

The structure of Xn was firstly identified by Verzele et al. (1957). However, the beneficial pharmacological properties of Xn were not appreciated until 1990s, including antioxidant, anti-inflammatory, antibacterial, antiviral, antifungal, and antiplasmodial activity (Liu et al., 2015). In recent years, increasing evidences suggested the anticancer activity of Xn against

Abbreviations: ALL, acute lymphoblastic leukemia; $\mathrm{AR}^{-}$, hormone-refractory; $\mathrm{AR}^{+}$, hormone-sensitive; ASCL1, achaete scute complex like 1; CCA, cholangiocarcinoma; EGCG, epigallocatechin-3-gallate; EGFR, epidermal growth factor receptor; HCC, hepatocellular carcinoma; HPV, human papillomavirus; MCF-7/ADR, adriamycin-resistant MCF-7; MDR1, multidrug resistance 1; NSCLC, non-small cell lung cancer; PCa, prostate cancer; STAT3, signal transducer and activator of transcription 3; TRAIL, tumor necrosis factor-related apoptosis-inducing ligand; TRAMP, transgenic adenocarcinoma of the mouse prostate; $\mathrm{Xn}$, xanthohumol. 
NSCLC, leukemia, HCC, breast cancer, PCa, CCA, glioblastoma, pancreatic cancer, colon cancer, cervical cancer, melanoma, thyroid cancer, laryngeal squamous cell carcinoma (LSCC), and ovarian cancer.

Present review firstly summarized the present knowledge of potential chemopreventive or therapeutic effects of Xn. Initially, we described the current evidence on anticancer activity of Xn including both in vitro and in vivo studies depending on various organs of the body, meanwhile the underlying mechanisms in each cancer type were discussed. Subsequently, the shortcomings of these studies were summarized, and which areas deserved to be further investigated. Additionally, the safety and imitations for clinical applications were presented. This review would contribute to the proceed for anticancer study of $\mathrm{Xn}$, on the other hand, provide a reference for development of anticancer drugs.

\section{RESPIRATORY SYSTEM CANCERS}

\section{Non-small Cell Lung Cancer}

Almost 1.6 million people are affected by lung cancer, and its 5-year survival rate is as low as 15\% (Chen et al., 2014). Lung cancer mainly consists of two categories by histological classification: NSCLC and small cell lung cancer. However, the NSCLC patients account for about $85 \%$ of lung cancer patients per year (Yang and Lin, 2016).

NSCLC is classified as adenocarcinoma and squamous cell carcinoma (Kuribayashi et al., 2016). Most studies on antiNSCLC effect of Xn are mainly focused on adenocarcinoma. $\mathrm{Xn}$ showed greater anti-proliferative activity against NSCLC adenocarcinoma cells A549 than H1563. The A549 cells appeared to have a high basal level of phosphorylated ERK1/2. Data suggested that the blockade of the Ras/Raf/ERK cascade was highly beneficial, especially when cancer cells growth was heavily dependent on MEK/ERK activity. Xn treatment caused concentration-dependent decrease of ERK1/2 phosphorylation in A549 cells. Xn also significantly reduced the phosphorylation of p90RSK and CREB, the downstream ERK1/2 substrates. The CREB is a well-known transcription factor whose active form binds to certain DNA sequences called cAMP response elements (CRE) and is responsible for the regulation of several target genes including cell cycle regulative gene (cyclin A, cyclin D1). As such, Xn treatment of A549 cells induced the up-regulation of cell cycle regulators p53 and p21 as well as down-regulation of cyclin D1 (Slawinska-Brych et al., 2016).

Promoting ROS over-production may be another important mechanism of how Xn induces apoptosis in A549 cells. Mitochondria are subcellular organelles whose primary function is to produce ATP through oxidative phosphorylation (OXPHOS). By dissecting the multiple steps of mitochondria OXPHOS with extracellular flux analysis, Zhang et al. (2015) found that Xn specifically inhibited the activity of complex I, and had little or no effects on complexes II, III, and IV. Inhibition of complex I (NADH-ubiquinone oxidoreductase) by Xn resulted in ROS over-production, which ultimately induced the apoptosis of A549 cells.

Summarized above the mentioned, Xn suppressed the ERK1/2 phosphorylation and promoted ROS over-production, ERK1/2 and ROS may be the target of Xn in NSCLC. However, the overexpression of ERK1/2 or ROS scavenger was not further used upon Xn treatment. Therefore, present studies were insufficient to confirm that ERK1/2 and ROS mediated the proliferation inhibition and apoptosis induction of Xn in NSCLC. Moreover, with the exception of in vitro studies, the anticancer activity of $\mathrm{Xn}$ in NSCLC should be verified through in vivo studies.

\section{LYMPHATIC HEMATOPOIETIC CANCERS}

\section{Leukemia}

As the most frequent type of childhood cancer, ALL occurs particularly in children between the ages of 2 and 5 years. Currently, drug resistance during chemotherapy and the insurgence of neurological disorders emerge as the major obstacles for ALL cancer treatment (Cuvertino et al., 2017).

It has been reported that $\mathrm{Xn}$ can induce growth arrest and apoptosis in B-ALL cells. Moreover, Xn preserved equal cytotoxicity in adriamycin resistant ALL cells L1210, while long-term exposure of Xn to ALL cells improved sensitivity to chemotherapeutic drugs. These results suggested that Xn can effectively overcome the drug resistance of ALL, and promoted the sensitivity of chemotherapeutic drugs. In ALL-like xenograft mouse model, administration of Xn (50 $\mu \mathrm{g} / \mathrm{mouse} /$ day in $200 \mu \mathrm{L}$ PBS) significantly delayed the insurgence of neurological disorders, led to the increase of animal life span. This increased life expectancy was linked to a reduced ability of leukemic cells to infiltrate the CNS, as a delay of neurological symptoms was
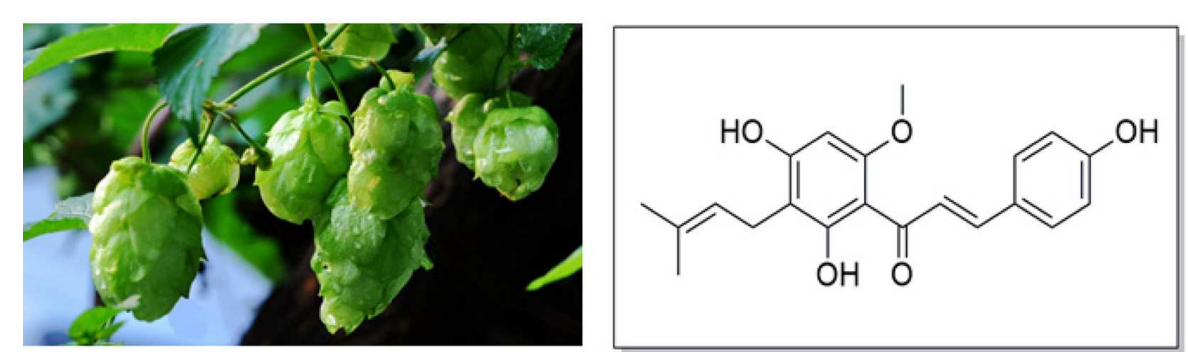

FIGURE 1 | Hops (Humulus lupulus L.) and structure of Xn. 
observed. Interestingly, Xn did not induce resistance but drug adaptation, characterized by the down-regulation of FAK, AKT, and NF- $\mathrm{B}$ activities rendering cells less invasive and more susceptible to cytotoxic drugs (Benelli et al., 2012). Although the antileukemic activity of $\mathrm{Xn}$ both in vitro and in vivo have been investigated, positive drug group needs to be added in further studies, which can evaluated the anti-leukemic activity of $\mathrm{Xn}$ accurately and effectively.

In addition to ALL, $\mathrm{Xn}$ induced the apoptosis of chronic myeloid leukemia cells KBM-5, which attributed to the decrease of NF- $\kappa \mathrm{B}$ activation via modifying IKK and p65 (Harikumar et al., 2009). It has been reported that PI3K/Akt, NF-кB, etc. signaling pathways can be activated by the oncogenic $\mathrm{Bcr}-\mathrm{Abl}$ tyrosine kinase in $\mathrm{Bcr}-\mathrm{Abl}(+)$ myeloid leukemia cells, eventually led to proliferation, transformation, and apoptosis resistance (Vakana and Platanias, 2011). Xn strongly inhibited Bcr-Abl expression in $\mathrm{K} 562$, a $\mathrm{Bcr}-\mathrm{Abl}(+)$ myeloid leukemia cells. Unfortunately, the effects of Xn on the PI3K/Akt, NF-кB, etc. signaling pathways were not determined in $\mathrm{K} 562$, led to the precise molecular mechanism of $\mathrm{Xn}$ on B-CLL cells remained unknown (Monteghirfo et al., 2008).

\section{DIGESTIVE SYSTEM CANCERS}

\section{Hepatocellular Carcinoma}

The 5-year survival rate of HCC patients is $50-70 \%$ (Xie et al., 2015). Currently, liver transplantation is the only effective curative modality. However, surgery is often non-efficacious due to the potential metastasis of HCC. Therefore, there is an urgent need to find targeted anticancer agents with less toxic profiles for HCC patients (Thein et al., 2017). Kunnimalaiyaan et al. (2015a) found that treatment with Xn (5 $\mu \mathrm{M}$ or higher) for 4 days suppressed the cells viability, confluency, and colony forming ability of HCC cells (Huh-7, HepG2, Hep3B, and SKHep-1), which was indicated by increased expression of proapoptotic proteins (cleaved caspase- 3 and c-PARP) and reduced expression of anti-apoptotic proteins (cyclin D1, survivin, and Mcl-1). Notch signaling pathway was involved in the anti-HCC effect of Xn, as evidenced by the decreased expression of Notch1 and HES-1 proteins (Kunnimalaiyaan et al., 2015a), and the antiproliferative effect of Xn in HCC can be reversed by ectopic Notch1 expression (Kunnimalaiyaan et al., 2015a). Conversely, another study reported that Xn exhibited neither cytotoxic nor genotoxic to the HepG2 cells at concentrations up to $10 \mu \mathrm{M}$ for $24 \mathrm{~h}$ (Plazar et al., 2007), which was consistent with the finding of $\mathrm{Ho}$ et al. (2008). They found the $\mathrm{IC}_{50}$ values of $\mathrm{Xn}$ for HA22T/VGH and Hep3B were 108 and $166 \mu \mathrm{M}$, respectively (Ho et al., 2008). Through comparative analysis, the inconsistent results might be due to the different treatment time (4 days vs. $24 \mathrm{~h})$.

In addition to the growth suppression and apoptosis induction, a significant protective effect of $\mathrm{Xn}$ against pro-carcinogens induced DNA damage was observed at concentrations as low as $10 \mathrm{nM}$ (Plazar et al., 2007). Moreover, Xn showed no effect on primary human hepatocytes viability at $100 \mu \mathrm{M}$ or higher, while suppressed proliferation and migration of HCC cells (HepG2 and Huh7) at $25 \mu \mathrm{M}$ via inhibiting NF- $\kappa$ B activity and IL-8 expression (Dorn et al., 2010). This finding suggested that Xn may be a safe and effective agent targeted cancer cells for HCC treatment, which needed to be further verified in vivo.

\section{Cholangiocarcinoma}

As the first most common primary biliary malignancy and the second most common primary hepatic malignancy, CCA accounts for $3 \%$ of gastrointestinal tumors. Surgical restriction is the best treatment regimen for CCA. However, not all CCA patients are good candidates for curative surgery and complete surgical restriction is often followed by local recurrence with unsatisfactory 5-year survival rate (Rizvi and Gores, 2013). It has been reported that administration of $\mathrm{Xn}$ orally in drinking water to CCA bearing nude mice reduced tumor growth. Tumor tissues from Xn-treated mice exhibited suppressed tumor growth and increased apoptosis as demonstrated by decreased Ki67 positive cells and increased TUNEL positive cells (Dokduang et al., 2016). However, it was difficult to guarantee the identity among individuals through administration of Xn orally in drinking water. Because of the poor solubility in water, Xn can be dispersed in suspending agent (e.g., sodium carboxymethyl cellulose), and intragastric administrated to CCA mice.

Additionally, the STAT3 activation was reduced in Xn-treated mice. In vitro study also found that Xn significantly inhibited cell proliferation in both KKU-M139 and KKU-M214 through the suppression of STAT3 activation. In addition, Akt and NF- $\mathrm{B}$ p65 nuclear translocation activity was decreased after treatment with $\mathrm{Xn}$ in both the IL-6-induced CCA cells and the CCA inoculated mice (Dokduang et al., 2016). In view of the fact that STAT3 activation was regulated by Akt/NF- $\kappa$ B signaling pathway, the possible mechanisms by which $\mathrm{Xn}$ suppressed STAT3 activation in CCA may be due to Akt/NF- $\mathrm{B}$ signaling inhibition.

\section{Pancreatic Cancer}

Pancreatic cancer is now the third leading cause of cancerrelated death in the United States, with pancreatic ductal adenocarcinoma (PDAC) representing the majority of these cases. Despite a steady increase in survival for most cancers over the decades, the 5-year survival of PDAC remains essentially unchanged at $8 \%$ (Siegel et al., 2017). Therefore, there is an urgent need to develop new therapeutic strategies with low toxicities to treat PC. Xn treatment was found to arrest cell cycle and induce apoptosis in pancreatic cancer cells (PANC-1, BxPC3) via decreasing STAT3 phosphorylation and its downstream targeted genes expression, such as cyclin D1, survivin, and $\mathrm{Bcl}-\mathrm{xL}$. The further in vivo study demonstrated that $\mathrm{Xn}$ can suppress the pancreatic cancer growth in a xenograft nude mouse model. However, the STAT3 phosphorylation and its downstream targeted genes expression in tumor tissue were not determined, so that STAT3 signaling pathway whether acted as the key molecular target of $\mathrm{Xn}$ in pancreatic cancer pending further study (Jiang et al., 2015). Another study suggested that Xn reduced the proliferation of pancreatic cancer cells (AsPC-1, L3.6pl, PANC-1, MiaPaCa-2, 512, and 651) in a dose and time 
dependent manner. The growth suppression effect of Xn was due to increased apoptosis via the inhibition of the Notch1 signaling pathway, as evidenced by reduction in Notch1, HES-1, and survivin both at mRNA as well as protein levels (Kunnimalaiyaan et al., 2015b). The relationship between STAT3 and Notch1 signaling pathway has been reported in multiply kinds of cancer, either coordination or interaction (LeComte and Spees, 2016). The detail relationship in Xn-treated pancreatic cancer required further investigation.

\section{Colon Cancer}

Colorectal cancer is currently the second most common cancer in women and the third most common in men, with 1.4 million new cases annually. The global burden of colorectal cancer is expected to increase by $60 \%$ to more than 2.2 million new cases and 1.1 million deaths by 2030 (Ouban, 2018). Phytochemicals in foods or traditional medicines have become one of the multi-therapy approach choices for cancer treatment. Six prenylated flavonoids isolated from hops were tested for their anti-proliferative activity in colon cancer cells (HT-29). Result showed that Xn, DX (dehydrocycloxanthohumol) and IX (isoxanthohumol) dose-dependently decreased HT-29 proliferation $(0.1-100 \mu \mathrm{M})$ (Miranda et al., 1999). Among them, Xn exhibited the best cytotoxic activity. The other five prenylated flavonoids are the Xn structural analogs, therefore, their structure-activity relationship may provide reference for further structural modification. In 40-16 human colon cancer cells, Xn significantly reduced its proliferation with $\mathrm{IC}_{50}$ values of $4.1,3.6$, and $2.6 \mu \mathrm{M}$ for 24,48 , and $72 \mathrm{~h}$, respectively (Pan et al., 2005). The cytotoxicity of Xn on HCT-15 was also evaluated. Xn showed potent cytotoxicity against HCT-15 with $\mathrm{IC}_{50}$ values of $3.6 \mu \mathrm{M}$ after $24 \mathrm{~h}$ of treatment. Moreover, Xn clearly decreased the expression of the drug efflux genes including ABCB1 (MDR1), ABCC1 (MRP1), ABCC2 (MRP2), and ABCC3 (MRP3) (Lee et al., 2007), which suggested that $\mathrm{Xn}$ might be used in combination with other anticancer chemotherapeutic agents to reduce the drug resistance by inhibiting the efflux drug transporters.

\section{GENITOURINARY ORGAN CANCERS}

\section{Breast Cancer}

Because of the crucial roles of progesterone receptor (PR), estrogen receptor (ER) and human epidermal growth factor receptor 2 (HER2) in breast cancer carcinogenesis, it is classified based on their expression: (1) $\mathrm{ER}^{+}$, estrogen receptor positive; (2) $\mathrm{HER} 2^{+}$, overexpressing human epidermal growth factor receptor 2, which can be $\mathrm{ER}^{+}$or $\mathrm{ER}^{-}$; (3) TNBCs, triple negative subtype that do not express estrogen, progesterone, and HER2 receptors. Up to date, effective therapeutics for TNBCs has not been found (Jitariu et al., 2017).

Hs578T and MDA-MB-231 have been used as TNBCs extensively in in vitro studies (Bassey-Archibong et al., 2016). Treatment with $\mathrm{Xn}$ for $24 \mathrm{~h}$ inhibited the growth of MDAMB-231 and Hs578T with $\mathrm{IC}_{50}$ values of 6.7 and $4.78 \mu \mathrm{M}$, respectively. $\mathrm{Xn}$ also inhibited the invasive phenotype of Hs578T and MDA-MB-231 (Kim et al., 2013). The caspase- and mitochondria-dependent apoptotic pathway mediated the apoptosis-induced effect of Xn on MDA-MB-231 cells (Yoo et al., 2014). In addition, it was reported that the exposure of Xn $(10 \mu \mathrm{M}, 48 \mathrm{~h})$ to MCF-7 cells can inhibit cell proliferation, accompanied with a significant reduction in alkaline phosphatase (ALP) activity (Guerreiro et al., 2007). The abnormal expression of ALP isoenzymes, identified as a prognostic biomarker, was found in multiple malignant tissues (Wada et al., 2001). In vivo study indicated that oral administration of $\mathrm{Xn}$ to MCF-7 bearing nude mice caused central necrosis within tumor tissues, focal proliferation areas, reduced inflammatory cell number, decreased microvessel density, and increased percentage of apoptotic cells (Monteiro et al., 2008). It has been reported that MCF-7 was the $\mathrm{ER}^{+}$breast cancer cells, while MDA-MB-231 belongs to TNBCs. Compared with the MCF-7, MDA-MB-231 exhibits stronger metastasis ability and more susceptibility to tumorigenicity in nude mice. Further in vivo studies can be conducted in MDA-MB-231 bearing nude mice, to evaluate the difference between $\mathrm{ER}^{+}$and TNBCs subtype after Xn treatment, which may decide the direction of clinical studies.

The further in vitro study focused to MCF-7/ADR cell line, which is resistant to many kinds of anticancer drugs, to evaluate the sensitivity of this cell line to Xn. Results showed that Xn dose-dependently induced apoptosis, decreased cell viability and arrested the cell cycle of MCF-7/ADR cells. When detecting the apoptosis related proteins, including $\mathrm{Bax}, \mathrm{Bcl}-2$, procaspase-3, and cleaved-PARP, the increased level of $\gamma$-H2AX was observed. This finding indicated the cytotoxic effect of Xn possibly had relationship with its genotoxic effect. Moreover, Xn could downregulate the cancer stemness characters in MCF-7/ADR cells, as evidenced by the decreased SP percentage in MCF-7/ADR cells upon Xn treatment. SP cells (breast cancer stem-like cells) are characterized by their high clonogenicity, increased migration, and resistance to the fluorescence dyes. Therefore, agents that can reduce the SP phenotype are currently in vogue in cancer therapeutics (Liu M. et al., 2016). Moreover, the radio- and chemo-sensitizing studies of $\mathrm{Xn}$ on MCF-7/ADR cells showed that Xn can recover the sensitivity of MCF-7/ADR cells to radiation and adriamycin therapies, which inhibited EGFR, MDR1, and STAT3 expression. These results suggested that Xn may be a potent chemo- and radio-sensitizer, which deserved to be further verified in animal or human (Kang et al., 2013).

\section{Prostate Cancer}

The PCa is the most common death in men worldwide (Cao et al., 2016). PCa cells can be classified as $\mathrm{AR}^{+}$(hormone-sensitive) subtype and $\mathrm{AR}^{-}$(hormone-refractory) subtype. LNCaP is the typical $\mathrm{AR}^{+}$cells, while PC-3 and DU145 belong to $\mathrm{AR}^{-}$cells. These cells were all highly sensitive to $\mathrm{Xn}$ at a concentration range of 20-40 $\mu \mathrm{M}$, The primary mechanism of action of Xn was to induce cell apoptosis as demonstrated by the binding of annexin V-FITC, cleavage of PARP-1, activation of procaspase-3, -8, and -9 , mitochondrial depolarization, and release of cytochrome $c$ from mitochondria. Induction of apoptosis by Xn was associated with the inhibition of prosurvival Akt, NF-кB, and p-mTOR as 
well as NF-кB-regulated anti-apoptotic Bcl-2 and survivin (Deeb et al., 2010). In malignant PCa cells PC3 and non-tumorigenic prostate hyperplasia cells $\mathrm{BPH}-1$, Xn dose-dependently decreased cells viability $(2.5-20 \mu \mathrm{M})$ and increased early and late apoptotic cells (Colgate et al., 2007). Interestingly, BPH-1 cells were more sensitive to growth inhibitory and pro-apoptotic effects of Xn than cancerous PC-3 cells. Thus, the more potential efficacy of Xn may be laid in precancerosis or prostate hyperplasia, suggesting that Xn served as a promising chemopreventive agent in PCa.

The in vivo study was conducted in the TRAMP transgenic mice, a PCa animal model. Oral administration of Xn did not prevent the initiation of carcinogenesis but decreased the average urogenital tract weight, inhibited the growth of poorly differentiated prostate carcinoma and delayed the tumor progression. Further in vitro study indicated that $\mathrm{Xn}$ can inhibit proliferation and reduce cell migration and invasion of DU145 and PC3 at low micromolar concentration, these effects were associated with down-regulated FAK and AKT phosphorylation, as well as increased ROS (Vene et al., 2012). TRAMP transgenic mice act as a spontaneous PCa model, the degree of malignancy is increased over time. In this study, Xn was administrated by gavage to TRAMP mice beginning at 4 weeks and continuing until the animals were 24 weeks old, therefore, which was considered to be a preventive mode. The results indicated that Xn was a promising chemopreventive agent for PCa indeed. Further study can be conducted in a therapeutic model.

TRAIL, an endogenous ligand, plays a crucial role in anti-tumor immunity and immune surveillance (Chen et al., 2017), while LNCaP PCa cells are resistant to TRAIL-induced apoptosis. It should be noted that $\mathrm{Xn}$ increased sensitivity of LNCaP to TRAIL, which maybe another important mechanism of Xn-induced PCa cells apoptosis (Klosek et al., 2016).

\section{Cervical Cancer}

Cervical cancer constitutes a leading cause of morbidity and cancer deaths in women throughout the world. Approximately two-thirds of the patients are diagnosed with locally advanced cervical cancer, showing disappointing survival rates (Marquina et al., 2018). Thus, an effective and safe therapy for cervical cancer is urgently needed. Yong et al. (2015) found the induction of apoptosis by $\mathrm{Xn}$ on $\mathrm{Ca}$ Ski cervical cancer cell line. Additionally, Xn mediated $S$ phase arrest in cell cycle analysis and increased activities of caspase-3, -8, and -9. On the other hand, the expression of cleaved PARP, p53, and AIF were increased, while Bcl-2 and XIAP were decreased in a dose-dependent manner. These findings indicate that $\mathrm{Xn}$ induced apoptosis might involve intrinsic and extrinsic apoptotic pathways (Yong and Abd Malek, 2015). Obviously, the anticancer activity of Xn against cervical cancer was only investigated in Ca Ski cells in vitro to date. Therefore, more types of cervical cancer cells (e.g., Hela and $\mathrm{SiHa}$ ) and in vivo model may be supposed to evaluate the anticancer activity of Xn against cervical cancer.

\section{Ovarian Cancer}

Ovarian cancer is the fifth most common cancer in the United States and is the deadliest gynecologic malignancy. Due to the difficulty of early detection, most cases of ovarian cancer are stage III or IV when discovered resulting in only a 15$20 \%$ cure rate (Musella et al., 2018). After exposure to A-2780 ovarian cancer cells for 2 days and 4 days, Xn induced highly cytotoxicity with $\mathrm{IC}_{50}$ values of 0.52 and $5.2 \mu \mathrm{M}$, respectively (Miranda et al., 1999). Significant growth inhibition and downregulation of Notch1 transcription and protein expression were found following Xn treatment in SKOV3 and OVCAR3 cells (Drenzek et al., 2011). However, it has been reported that metastasis is the major cause of morbidity and mortality in patients with ovarian cancer, especially the epithelial ovarian cancer (Weidle et al., 2016). Many efforts can be made to evaluate the metastasis ability upon Xn treatment, in addition to cytotoxicity and proliferation.

\section{HEAD AND NECK CANCERS}

\section{Glioblastoma}

Glioblastoma multiforme (GBM), a grade IV malignant glioma, is the most aggressive primary brain tumor with a poor prognosis in adults. With the gradually increasing drug resistance with TMZ treatment, the first line chemotherapeutic drug in clinical gliomas therapy, innovative replacement or adjuvant drugs for glioblastomas are urgently needed (Reitman et al., 2018). Xn decreased viability and induced apoptosis of T98G cells in a timeand concentration-dependent manner. These effects involved activation of caspase-3, -9 , and PARP cleavage as well as increase of intracellular ROS production (Festa et al., 2011). Chen et al. (2016) found that Xn significantly induced the apoptosis and reduced cell viability in U87 cells. In view of the key roles of miRNAs in the development of glioblastoma, the microarray analysis was used to identify the abnormal expressed miRNAs under Xn treatment. Results showed that miR-204-3p was the most up-regulated miRNA. The ERK/c-Fos pathway mediated the effect of Xn on miR-204-3p expression. Furthermore, miR204-3p targeting IGFBP2/AKT/Bcl2 pathway regulated U87 cells death (Chen et al., 2016). The miRNAs serves as the important member of ncRNAs. The ncRNAs are a heterogeneous class of transcribed RNA molecules. Several studies have shown that ncRNAs dysregulation is a common central event occurring in multiple cancers and has the potential of being therapy targets (Wangyang et al., 2018). Recently, increased evidences suggested the ncRNAs mediated the anticancer activity of phytochemical constituents (Gulei et al., 2017). The anticancer activity of Xn whether also involved other ncRNAs, e.g., IncRNAs and circRNAs, remains unknown.

\section{Thyroid Cancer}

There has been a worldwide thyroid epidemic with 470,000 women and 90,000 men being diagnosed during the last two decades. Though the disease-specific mortality of thyroid cancer is low, unwarranted or inadequate surgery is associated with increased morbidity making proper management important 
(D'Cruz et al., 2018). The promotion of Xn on $\mathrm{I}^{-}$uptake of FRTL5 thyrocytes suggested that Xn might be an interesting candidate for increasing the sensitivity of radiotherapy on thyroid cancer (Radovic et al., 2005). Furthermore, treatment of medullary thyroid cancer cells MTC with Xn dose-dependently inhibited proliferation and down-regulated ASCL1, a possible malignant phenotype in thyroid cancer (Cook et al., 2010). However, the inhibition rate reminds lower than $50 \%$ after 4 days of treatment with $30 \mu \mathrm{M} \mathrm{Xn}$. Therefore, whether Xn exhibits the potent anticancer activity in thyroid cancer, similarly to other cancers, needs to be further verified.

\section{Laryngeal Squamous Cell Carcinoma}

Laryngeal squamous cell carcinoma is the most common malignancy of the head and neck worldwide. The 5-year survival rates for laryngeal cancer patients with regional and metastatic LSCC significantly decreased within last three decades, irrespective of the therapy applied (Cosetti et al., 2008). Therefore, there is a need for discovery of novel, more effective therapeutic agents. It has been reported that Xn treatment reduced the cell viability of LSCC cells (RK33 and RK45), but had very low or no toxicity in normal cells (rat oligodendroglia-derived cells, OLN-93 and human skin fibroblasts, HSF) (Slawinska-Brych et al., 2015). Moreover, Xn exhibited potent cytotoxicity in SCC4 cells, which may be associated with suppression on $\mathrm{Mcl}-1$ and $\mathrm{Bcl}-2$ expression, as well as PARP, p53, and AIF activation (Li et al., 2016). Although changes in these protein expressions or activities have been observed upon Xn treatment, lack of knockdown or overexpression methods to further determine the molecular target of Xn in LSCC.

\section{OTHER CANCERS}

\section{Melanoma}

It is known that melanogenesis can be induced by several extracellular stimuli except ultraviolet (UV) light, such as isobutylmethylxanthine (IBMX) (Siegel et al., 2017). Xn dose-dependently $(0.5-10 \mu M)$ inhibited IBMX-induced melanogenesis in B16 melanoma cells, which was associated with the reduced tyrosinase enzyme activity (Koo et al., 2008). Tyrosinase, a bifunctional enzyme, was responsible for melanin production (Hearing and Jimenez, 1987). In another melanoma cells SK-MEL-2, Xn showed potent cytotoxicity by inhibiting the activity of DNA topoisomerase I (Topo I), suggesting Xn may be a novel Topo I inhibitor (Lee et al., 2007). Topo I is a nuclear enzyme engaged in adjustment of DNA topological structure during cell cycle. Inhibition of this enzyme results in DNA strand breaks, ultimately leads to proliferation inhibition and apoptosis induction. Consequently, Topo I has a great potential as a target for the treatment various cancers. For instance, 10-hydroxycamptothecin, a Topo I inhibitor, has been used as a broad-spectrum anticancer drug in clinical practice (Gokduman, 2016). Thus, the broad-spectrum anticancer activity of Xn might be attributed to its inhibition on Topo I activity.

\section{DISCUSSION AND PERSPECTIVE}

\section{Common Diet With Cancer Preventive and Therapy Phytochemicals}

Cancer is a complex multifactorial disease, in which normal cells are transformed into malignant cells acquiring several properties including enhanced proliferation and apoptosisresistance (Wang et al., 2014; Ouyang et al., 2016). Due to the mechanisms of carcinogenesis and cancer development are still unclear, preventive intervention is becoming scientifically practical for treating cancers (Kelloff et al., 1994; Sporn and Suh, 2002). Several studies have demonstrated that diet represents a new strategy in cancer management, that means prevention starts from what we drink and what we eat (Rossi et al., 2014). Dietary factors, found in solid foods and beverages, contribute to the prevention of approximately 30\% of cancers in industrialized countries, and diet acts as the second preventive approach in cancer (Rodriguez-Casado, 2016). It has been observed that numerous phytochemical components, frequently present in beverages, show potent chemopreventive or therapeutic properties that selectively affects cancer cells (Wu et al., 2017). For instance, EGCG, the major class of flavonoids isolated from green tea (Schramm, 2013), showed a chemopreventive effect on a variety of human cancers in vitro and in vivo, and even in recent clinical trials (Du et al., 2012; Zhao et al., 2015, 2016). The well-known stilbenoid resveratrol, found in grape and red wine, exerted anticancer activity in various malignant cancers (Liu et al., 2007; Zhang et al., 2014; Pan et al., 2017). Xn was the most abundant flavonoid isolated from the hop plant $(H$. lupulus L.), with a concentration of up to $0.96 \mathrm{mg} / \mathrm{L}$ in most beers (Stevens et al., 1999), and reach $3.5 \mathrm{mg} / \mathrm{L}$ in dark beer through using colored malt (Magalhães et al., 2008). Over almost 30 years, increasing evidences have emerged concerning the anticancer activity of Xn.

\section{Anticancer Activity of $\mathbf{X n}$}

The data from the in vitro studies indicated that $\mathrm{Xn}$ was able to inhibit both carcinogenesis and metastasis. As summarized in Table 1, exposure of cancer cells to Xn inhibited the proliferation, migration, and invasion, as well as induced apoptosis and cell cycle arrest. The range of anticancer activity covered multiple parts of body including respiratory system, digestive system, genitourinary system, and more. However, most of the in vitro studies were not compared with the standards of care, so that it would not provide a good reference for further in vivo animal and clinical studies.

Among these kinds of cancer, the activity of $\mathrm{Xn}$ on breast cancer and leukemia were systematically studied in vitro. In addition to the inhibition on carcinogenesis and metastasis, Xn can increase the chemo- and radio-sensitizing of adriamycinresistant MCF-7 cells (Kang et al., 2013), similar results were also observed in adriamycin-resistant ALL cells L1210 (Benelli et al., 2012). These findings indicated that Xn may work synergistically with the current traditional chemotherapy and radiotherapy treatments to decrease the doses that often result in toxicity and severe side-effects. 
TABLE 1 | Anticancer activity of Xn in vitro.

\begin{tabular}{|c|c|c|c|c|c|c|c|}
\hline Cancer types & & Cell lines & $\begin{array}{l}\text { Dose or } I_{50} \\
(\mu \mathrm{M})\end{array}$ & Duration (h) & Finding & Mechanism & Reference \\
\hline \multirow[t]{3}{*}{$\begin{array}{l}\text { Respiratory } \\
\text { system cancers }\end{array}$} & NSCLC & A549 & $5-25$ & 48 & $\begin{array}{l}\downarrow \text { Cell viability } \\
\downarrow \text { Proliferation } \\
\uparrow \text { Apoptosis }\end{array}$ & $\begin{array}{l}\downarrow \text { ERK1/2 } \\
\downarrow \text { p9ORSK kinases } \\
\downarrow \text { CREB } \\
\uparrow \text { p53 and p21 } \\
\downarrow \text { Cyclin D1 Cycle } \\
\text { arrest (G1 phase) } \\
\uparrow \text { Caspase-3 } \\
\text { activity }\end{array}$ & $\begin{array}{l}\text { Slawinska-Brych } \\
\text { et al., } 2016\end{array}$ \\
\hline & & A549 & $5-30$ & 6,24 & $\uparrow$ Apoptosis & $\begin{array}{l}\downarrow \mathrm{NADH} \\
\text { dehydrogenase } \\
\uparrow \text { Glycolysis } \\
\uparrow \mathrm{ROS}\end{array}$ & Zhang et al., 2015 \\
\hline & & A549 & $14,28,42$ & $24,48,72$ & $\begin{array}{l}\downarrow \text { Proliferation } \\
\uparrow \text { Apoptosis }\end{array}$ & $\begin{array}{l}\text { Cycle arrest } \\
\text { (S phase) } \\
\uparrow \text { Caspase-3, -8, -9 }\end{array}$ & Yong et al., 2015 \\
\hline & & $\begin{array}{l}\text { Chronic myeloid } \\
\text { leukemia KBM-5 }\end{array}$ & 50 & 4 & $\begin{array}{l}\uparrow \text { Apoptosis } \\
\downarrow \text { Invasion }\end{array}$ & $\begin{array}{l}\downarrow \mathbb{I K K} \text { activity } \\
\downarrow \text { IKB } \alpha \\
\text { phosphorylation } \\
\text { and degradation } \\
\downarrow \text { p65 nuclear } \\
\text { translocation } \\
\downarrow \text { NF-kB controlled } \\
\text { antiapoptotic genes } \\
\text { (Bcl-xL, CIAP-1, } \\
\text { CIAP-2, XIAP, } \\
\text { survivin, and } \\
\text { TRAF-2) }\end{array}$ & $\begin{array}{l}\text { Harikumar et al., } \\
2009\end{array}$ \\
\hline \multirow[t]{9}{*}{$\begin{array}{l}\text { Digestive } \\
\text { system cancers }\end{array}$} & $\begin{array}{l}\text { Hepatocellular } \\
\text { carcinoma }\end{array}$ & $\begin{array}{l}\text { Huh-7, HepG2, } \\
\text { Hep3B, and } \\
\text { SK-Hep-1 }\end{array}$ & 5 & 96 & $\begin{array}{l}\downarrow \text { Cell viability } \\
\downarrow \text { Colony forming } \\
\downarrow \text { Confluency ability }\end{array}$ & $\begin{array}{l}\downarrow \text { Notch1 } \\
\downarrow \text { HES-1 }\end{array}$ & $\begin{array}{l}\text { Kunnimalaiyaan } \\
\text { et al., } 2015 a\end{array}$ \\
\hline & & HepG2 & 10 & 24 & None & None & Plazar et al., 2007 \\
\hline & & $\begin{array}{l}\text { HA22TNGH and } \\
\text { Hep3B cells }\end{array}$ & $I_{50}=108,166$ & 24 & None & None & Ho et al., 2008 \\
\hline & $\begin{array}{l}\text { Cholangio- } \\
\text { carcinoma }\end{array}$ & $\begin{array}{l}\text { KKU-M214, } \\
\text { KKU-M139 }\end{array}$ & 20,50 & $24,48,72$ & $\downarrow$ Cell growth & $\downarrow$ STAT3 activation & $\begin{array}{l}\text { Dokduang et al., } \\
2016\end{array}$ \\
\hline & $\begin{array}{l}\text { Pancreatic } \\
\text { cancer }\end{array}$ & PANC-1, BxPC-3 & $5-100$ & 48 & $\begin{array}{l}\downarrow \text { Cell viability } \\
\downarrow \text { Colony formation } \\
\uparrow \text { Apoptosis }\end{array}$ & $\downarrow p-S T A T 3$ & Jiang et al., 2015 \\
\hline & & $\begin{array}{l}\text { AsPC-1, PANC-1, } \\
\text { L3.6pl, } \\
\text { MiaPaCa-2, 512, } \\
651\end{array}$ & 10 & $48-96$ & $\downarrow$ Proliferation & $\begin{array}{l}\downarrow \text { Notch1 } \\
\downarrow \text { HES-1 } \\
\downarrow \text { Survivin }\end{array}$ & $\begin{array}{l}\text { Kunnimalaiyaan } \\
\text { et al., 2015b }\end{array}$ \\
\hline & Colon cancer & HT-29 & $0.1-100$ & 48,72 & $\downarrow$ Cell viability & None & $\begin{array}{l}\text { Miranda et al., } \\
1999\end{array}$ \\
\hline & & $\begin{array}{l}\text { 40-16 colon } \\
\text { cancer cells }\end{array}$ & $\begin{array}{l}I_{50}=4.1,3.6 \\
2.6\end{array}$ & $24,48,72$ & $\downarrow$ Proliferation & None & Pan et al., 2005 \\
\hline & & HCT-115 & $\mathrm{IC}_{50}=10.2$ & 24 & $\downarrow$ Proliferation & $\begin{array}{l}\downarrow \mathrm{ABCB} 1 \\
\downarrow \mathrm{ABCC} 1, \mathrm{ABCC} 2, \\
\mathrm{ABCC} 3\end{array}$ & Lee et al., 2007 \\
\hline
\end{tabular}


TABLE 1 | Continued

\begin{tabular}{|c|c|c|c|c|c|c|c|}
\hline Cancer types & & Cell lines & $\begin{array}{l}\text { Dose or } \\
\mathrm{IC}_{50}(\mu \mathrm{M})\end{array}$ & Duration (h) & Finding & Mechanism & Reference \\
\hline \multirow[t]{7}{*}{$\begin{array}{l}\text { Genitourinary } \\
\text { organ cancers }\end{array}$} & \multirow[t]{3}{*}{$\begin{array}{l}\text { Breast } \\
\text { cancer }\end{array}$} & $\begin{array}{l}\text { MDA-MB-231 and } \\
\text { Hs578T }\end{array}$ & $\begin{array}{l}I_{50}=6.7 \\
4.78\end{array}$ & 24 & $\begin{array}{l}\downarrow \text { Proliferation } \\
\downarrow \text { Cell invasion }\end{array}$ & None & Kim et al., 2013 \\
\hline & & MDA-MB-231 & 10,20 & 48 & $\downarrow$ Cell viability & $\begin{array}{l}\downarrow \text { Bax } \\
\uparrow \text { Caspase-3, -9 }\end{array}$ & Yoo et al., 2014 \\
\hline & & MCF-7 & 10 & 48 & $\downarrow$ Proliferation & $\downarrow$ ALP isoenzymes & $\begin{array}{l}\text { Guerreiro et al., } \\
2007\end{array}$ \\
\hline & \multirow[t]{2}{*}{$\begin{array}{l}\text { Prostate } \\
\text { cancer }\end{array}$} & $\begin{array}{l}\text { Hormone-sensitive } \\
\left(\mathrm{AR}^{+}\right) \text {: LNCaP; } \\
\text { hormone- } \\
\text { refractory }\left(\mathrm{AR}^{-}\right) \text {: } \\
\text { PC-3 and DU145 }\end{array}$ & 20,40 & 72 & $\begin{array}{l}\downarrow \text { Cell viability } \\
\uparrow \text { Apoptosis }\end{array}$ & $\begin{array}{l}\downarrow \mathrm{p}-\mathrm{AKT} \\
\downarrow \mathrm{NF}-\mathrm{kB} \text { p65 } \\
\downarrow \mathrm{p}-\mathrm{mTOR} \\
\downarrow \text { Bcl-2 } \\
\downarrow \text { Survivin }\end{array}$ & Deeb et al., 2010 \\
\hline & & $\begin{array}{l}\text { Hormone- } \\
\text { refractory }\left(\mathrm{AR}^{-}\right) \text {: } \\
\text { PC-3 and } \\
\text { DU145DU145, } \\
\text { PC3 }\end{array}$ & $2.5,5,10$ & 48,96 & $\begin{array}{l}\downarrow \text { Proliferation } \\
\downarrow \text { Cell migration } \\
\downarrow \text { Cell invasion }\end{array}$ & $\begin{array}{l}\downarrow p-F A K \\
\downarrow p-A K T\end{array}$ & Vene et al., 2012 \\
\hline & $\begin{array}{l}\text { Cervical } \\
\text { cancer }\end{array}$ & Ca Ski & $\begin{array}{l}I_{50}=59.96 \\
\pm 1.95 \\
34.01 \pm 1.13 \\
20.08 \pm 1.12\end{array}$ & $24,48,72$ & $\begin{array}{l}\downarrow \text { Proliferation } \\
\uparrow \text { Apoptosis }\end{array}$ & $\begin{array}{l}\downarrow \text { XIAP } \\
\uparrow \text { p53 } \\
\uparrow \text { Caspase-3, -8, -9 } \\
\text { Cycle arrest (S phase) }\end{array}$ & $\begin{array}{l}\text { Yong and Abd } \\
\text { Malek, } 2015\end{array}$ \\
\hline & $\begin{array}{l}\text { Ovarian } \\
\text { cancer }\end{array}$ & A-2780 & $\begin{array}{l}I_{50}=0.52 \\
5.2\end{array}$ & 48,96 & $\downarrow$ Proliferation & None & $\begin{array}{l}\text { Miranda et al., } \\
1999\end{array}$ \\
\hline \multirow{4}{*}{$\begin{array}{l}\text { Head and neck } \\
\text { cancers }\end{array}$} & Glioblastoma & T98G & 20 & 24,48 & $\begin{array}{l}\downarrow \text { Cell viability } \\
\uparrow \text { Apoptosis }\end{array}$ & $\begin{array}{l}\uparrow R O S \\
\uparrow p-E R K 1 / 2 \\
\uparrow p-p 38 \\
\uparrow \text { Caspase-3, -9 } \\
\uparrow \text { PARP cleavage }\end{array}$ & Festa et al., 2011 \\
\hline & $\begin{array}{l}\text { Thyroid } \\
\text { cancer }\end{array}$ & $\begin{array}{l}\text { Medullary thyroid } \\
\text { cancer cells MTC }\end{array}$ & $10,20,30$ & 96 & $\begin{array}{l}\downarrow \text { Proliferation } \\
\downarrow \text { Malignant phenotype }\end{array}$ & $\begin{array}{l}\uparrow \text { ERK1/2 } \\
\text { phosphorylation }\end{array}$ & Cook et al., 2010 \\
\hline & \multirow[t]{2}{*}{$\begin{array}{l}\text { Laryngeal } \\
\text { squamous } \\
\text { cell } \\
\text { carcinoma }\end{array}$} & RK33 and RK45 & $\begin{array}{l}I_{50}=12.3 \\
22.5\end{array}$ & 48 & $\begin{array}{l}\downarrow \text { Cell viability } \\
\uparrow \text { Apoptosis }\end{array}$ & $\begin{array}{l}\uparrow p 53 \text { and p21 } \\
\downarrow \text { Cyclin D1 } \\
\downarrow \text { ERK1/2 } \\
\text { phosphorylation } \\
\uparrow \text { Caspase-3, -8, -9 } \\
\text { Cycle arrest (G1 phase) }\end{array}$ & $\begin{array}{l}\text { Slawinska-Brych } \\
\text { et al., } 2015\end{array}$ \\
\hline & & ScC4 & $20,30,40$ & 48 & $\begin{array}{l}\downarrow \text { Proliferation } \\
\uparrow \text { Apoptosis }\end{array}$ & $\begin{array}{l}\downarrow \mathrm{BCl}-2 \\
\downarrow \mathrm{Mcl}-1 \\
\uparrow \mathrm{PARP} \\
\uparrow \mathrm{p} 53 \\
\uparrow \mathrm{AlF}\end{array}$ & Li et al., 2016 \\
\hline \multirow[t]{2}{*}{ Other cancers } & \multirow[t]{2}{*}{ Melanoma } & B16 & $\begin{array}{l}0.5,1,5 \\
10\end{array}$ & 48 & $\begin{array}{l}\downarrow \text { IBMX-induced } \\
\text { melanogenesis }\end{array}$ & $\begin{array}{l}\downarrow \text { Tyrosinase enzyme } \\
\text { activity, protein and } \\
\text { mRNA }\end{array}$ & Koo et al., 2008 \\
\hline & & SK-MEL-2 & $\mathrm{IC}_{50}=14.4$ & 24 & $\downarrow$ Proliferation & $\downarrow$ DNA topoisomerase I & Lee et al., 2007 \\
\hline
\end{tabular}


Apart from in vitro studies, the in vivo animal study showed that administration of $\mathrm{Xn}$ in drinking water to CCA bearing mice can reduce tumor growth (Dokduang et al., 2016). Intraperitoneal injecting Xn significantly delayed the insurgence of neurological disorders in ALL-like xenograft mouse model, led to the increase of animal life span (Benelli et al., 2012). Moreover, oral gavage of $\mathrm{Xn}$ to PCa mice decreased the average weight of the urogenital tract, inhibited the growth of poorly differentiated prostate carcinoma and delayed the advanced tumor progression (Vene et al., 2012). Unfortunately, only a handful of in vivo studies investigated the anticancer activity of $\mathrm{Xn}$, no clinical studies have been done in humans. Therefore, future in vivo animal and human studies should determine the effective dose and best route of $\mathrm{Xn}$ administration and side effects related to chronic administration.

Throughout these studies mentioned above, a comprehensive study was carried out only in ALL, including in vitro, in vivo, and the drug resistance. Accordingly, anticancer activity of Xn on ALL can be priorities for future intensive research.

\section{Anticancer Mechanisms of Xn}

Recently, the focus for cancer treatment has been shifted toward finding chemicals/strategies that specifically target crucial signaling molecules/ pathways in cancer (Basak et al., 2017). As shown in Table $\mathbf{1}$ and Figure 2, there were several lines of evidences suggesting the inhibition of $\mathrm{Xn}$ on Akt and NF- $\kappa \mathrm{B}$ signaling pathways, which played key roles in the maintenance malignant phenotypes and the metastasis of cancer.
The up-regulation of the pro-apoptotic proteins Bax, PARP, AIF, caspase-3, -8, -9 and down-regulation of anti-apoptotic protein $\mathrm{Bcl}-2$ were involved in the $\mathrm{Xn}$-induced cancer cells apoptosis, while the reduced Notch1, mTOR, STAT3, etc. mediated the inhibitive effect of Xn on cancer cells proliferation. Furthermore, $\mathrm{Xn}$ induced cell cycle arrest via regulating the expression of p53, p21, and cyclin D1. The down-regulation of FAK and MMP-2 expression was involved in the inhibition of $\mathrm{Xn}$ on migration and invasion of cancer cells. It is well known that MDR1, EGFR, and STAT3 are in significant associations with the multidrug resistant of cancer cells (Lee et al., 2011; Liu T. et al., 2016; Singh and Silakari, 2017). These proteins were down-regulated in Xn-treated MCF-7/ADR, suggesting that it was possible for $\mathrm{Xn}$ to act synergistically with the current traditional chemotherapy treatments and decrease the doses. Several studies presented conflicting results regarding the effect of Xn on ERK1/2 phosphorylation. For instance, Xn treatment increased ERK1/2 phosphorylation in thyroid cancer cells, while reduced ERK1/2 phosphorylation in larynx cancer cells. The reason may lie beyond the different effects of Xn on ERK1/2 phosphorylation was cell specific. Collectively, it can be easily noticed that Xn affects a series of key proteins associated with cancer cells proliferation, apoptosis, migration, invasion, and multidrug resistance. However, the exact molecular target of Xn remained unclear. Trace its root, lack of knockdown or overexpression methods to verify the aforementioned signaling molecules, and even no gene knockout animal models are used to evaluate the anticancer activity of Xn.

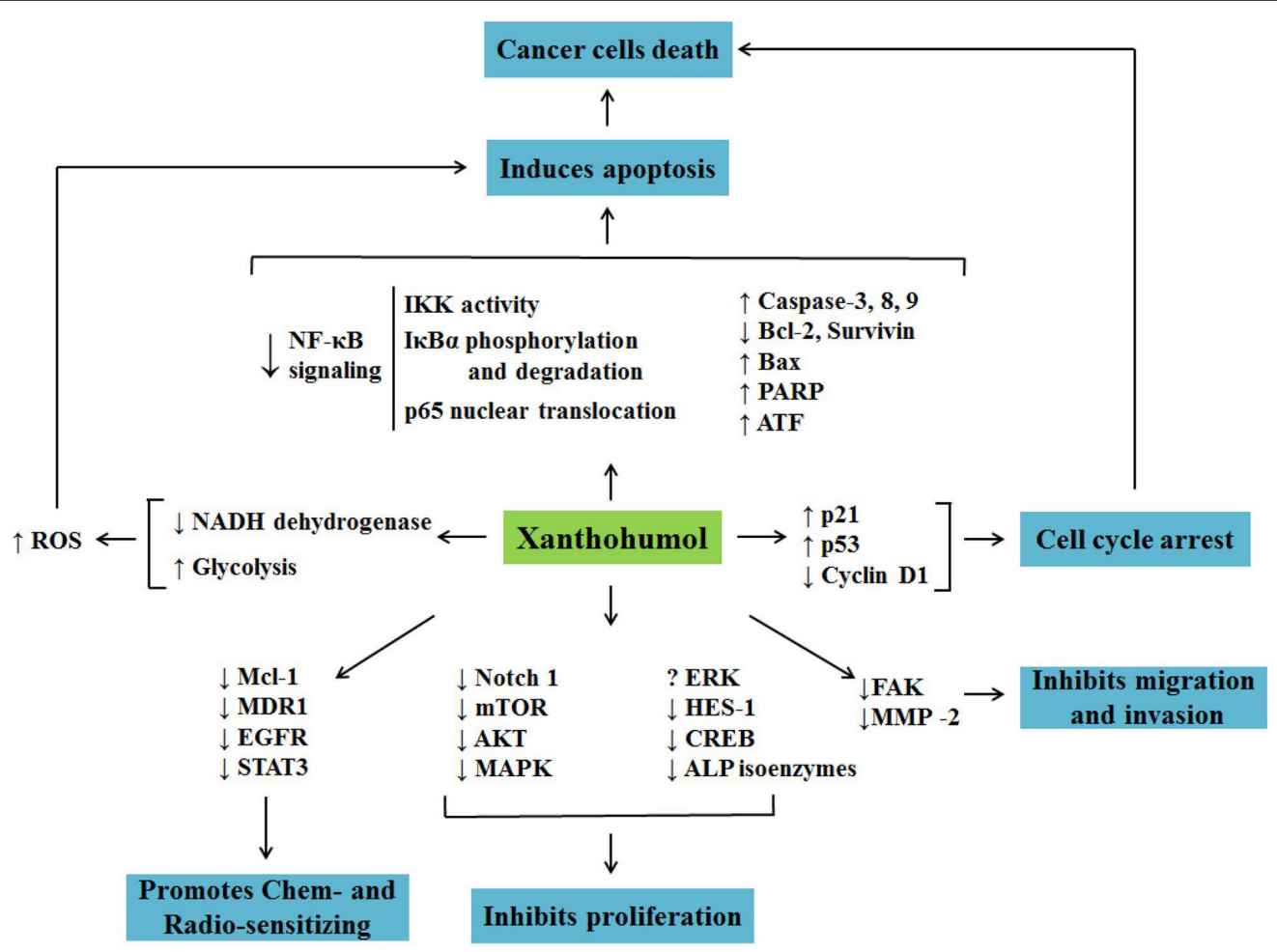

FIGURE 2 | Cellular and molecular mechanisms involved in anticancer activity of Xn. 


\section{Safety Studies for Xn Application}

During the course of anticancer activity studies, the effect of $\mathrm{Xn}$ on normal cells was simultaneously investigated. Xn exhibited very low or no toxicity in normal cells including human lung fibroblast cells (MRC-5), primary human hepatocytes, oligodendroglia-derived cells (OLN-93), and human skin fibroblasts (Dorn et al., 2010; Slawinska-Brych et al., 2015; Yong et al., 2015). These findings suggested that Xn specifically targeted cancer cells, on the other hand, Xn may be a safe and effective agent. Similar results were obtained in vivo. Vanhoecke et al. (2005) reported the results of a 4-week safety study of Xn in mice. Daily administration of $23 \mathrm{mg} / \mathrm{kg}$ BW did not cause any noticeable sign of toxicity in bone marrow, liver, exocrine pancreas, kidneys, muscles, thyroid, and ovaries (Vanhoecke et al., 2005). Moreover, Hussong et al. (2005) investigated the sub-chronic toxicity of $\mathrm{Xn}$ in female $\mathrm{SD}$ rats at daily doses up to $1000 \mathrm{mg} / \mathrm{kg}$ BW for 4 weeks, which causes weak hepatotoxicity in female SD rats, but does not influence reproduction and the development of two generations of offspring when given at a daily dose of $100 \mathrm{mg} / \mathrm{kg} \mathrm{BW}$. However, all of these in vivo studies were conducted in normal animal. Ideally chemopreventive agents given at safe doses effectively affected the carcinogenic process without toxicity. In order to simultaneously confirm the safety and effectiveness, the toxicity to normal organs should be measured in tumor-bearing mice after treatment with Xn.

\section{Limitations for Clinical Applications of Xn}

The current literatures available provide supporting evidence for the use of $\mathrm{Xn}$ as an anticancer agent, but there are several barriers from basic research to clinical practice. The low bioavailability is one of the important limitations (Venturelli et al., 2016). Female SD rats were treated with $1000 \mathrm{mg} / \mathrm{kg}$ BW, $80 \%$ of the applied Xn was excreted in feces and urine after stopping gavage for $48 \mathrm{~h}$ (Nookandeh et al., 2004). Avula et al. (2004) collected plasma, urine, and feces at varying time points and determined the Xn concentration, found that most of Xn were excreted in feces within $24 \mathrm{~h}$ of administration. These studies suggested the very low bioavailability of Xn after oral administration. In order to find out the underlying cause of low bioavailability, several pharmacokinetics studies in intestinal cells have been performed. A $70 \%$ of Xn added in the apical side of Caco-2 cells was found to accumulate inside the cells, and $93 \%$ of the intracellular Xn was localized in the cytosol and bound to cellular proteins, which may be the major factor responsible for poor oral bioavailability in vivo (Pang et al., 2007). Studies on the interaction of Xn with phosphatidylcholine membranes found that Xn inserted into lipid bilayers, thereby affected molecular organization and biophysical properties of the bilayer (Arczewska et al., 2013; Wesolowska et al., 2014). On this basis, the future studies on chemical structure modification and optimization of physical and chemical properties can focus on how to decrease specific binding of $\mathrm{Xn}$ to cytosolic proteins in intestinal epithelial cells and promote the rapid transport through the cell membrane, ultimately increase the bioavailability of Xn.
In addition to the low bioavailability, low extractive yield is another important factor restricting clinical application. Xn existed ubiquitously within hops plant in nature, which can be secreted as a part of the hop resin (Dresel et al., 2015). Originally, repeated chromatographic separations on silica gel were used to isolate and purify Xn. With the high-speed counter-current chromatography method being established, the extractive yield has been improved. However, it was still unable to meet the clinical needs (Chen et al., 2012). Therefore, a total synthesis method for Xn was further investigated (Khupse and Erhardt, 2007; Ellinwood et al., 2017). Unfortunately, the process was complicated and the overall yield is relatively low ( $10 \%$ overall yield from phloracetophenone after six steps) (Khupse and Erhardt, 2007). Learning from the development of Paclitaxel, further studies can focus on improvement of total synthesis yield. Paclitaxel in the market is known to be primarily obtained by this semi-synthetic route independent of isolation from plant (taxus chinensis)(Gueritte, 2001; Fu et al., 2009).

\section{CONCLUSION}

This review summarized the current advances on Xn, a prenylated flavonoid from hops ( $H$. lupulus L.) with potent anticancer activity to inhibit carcinogenesis and metastasis in many types of cancer, and additional properties that can be used as chemo- and radio-sensitizer. Multiple crucial signaling molecules and pathways were involved in the anticancer activity of Xn, such as Akt, NF-kB, ROS, ERK1/2, and so on. In view of these properties, Xn appears to be a good candidate in prevention and treatment for cancer and could be a potential weapon for new therapeutic strategies. However, more molecular biology techniques (e.g., knockdown and overexpression) should be applied in mechanism studies, more systematic in vivo studies are required to acquire a better understanding of the anticancer activity of Xn. The bioavailability and extraction yield remain to be improved in further clinical application.

\section{AUTHOR CONTRIBUTIONS}

C-HJ and T-LS reviewed the literature and wrote the article. $\mathrm{D}$-XX contributed valuable opinions in accomplishing the article. S-SW contributed valuable opinions in the construction of infrastructure of the article. W-QL guided and supervised writing of the article.

\section{FUNDING}

This work was supported by grants of the National Natural Science Foundation of China (Nos. 81703518, 81701577, and 81573718), Hunan Provincial Natural Science Foundation (No. 2018JJ3571), Scientific Research Project of Hunan Provincial Health and Family Planning Commission (No. B20180253), and Open-End Fund for the Valuable and Precision Instruments of Central South University (No. CSUZC201837). 


\section{REFERENCES}

Arczewska, M., Kaminski, D. M., Gorecka, E., Pociecha, D., Roj, E., SlawinskaBrych, A., et al. (2013). The molecular organization of prenylated flavonoid xanthohumol in DPPC multibilayers: X-ray diffraction and FTIR spectroscopic studies. Biochim. Biophys. Acta 1828, 213-222. doi: 10.1016/j.bbamem.2012. 10.009

Avula, B., Ganzera, M., Warnick, J. E., Feltenstein, M. W., Sufka, K. J., and Khan, I. A. (2004). High-performance liquid chromatographic determination of xanthohumol in rat plasma, urine, and fecal samples. J. Chromatogr. Sci. 42, 378-382. doi: 10.1093/chromsci/42.7.378

Basak, P., Sadhukhan, P., Sarkar, P., and Sil, P. C. (2017). Perspectives of the Nrf-2 signaling pathway in cancer progression and therapy. Toxicol. Rep. 4, 306-318. doi: 10.1016/j.toxrep.2017.06.002

Bassey-Archibong, B. I., Kwiecien, J. M., Milosavljevic, S. B., Hallett, R. M., Rayner, L. G., Erb, M. J., et al. (2016). Kaiso depletion attenuates transforming growth factor-beta signaling and metastatic activity of triple-negative breast cancer cells. Oncogenesis 5:e208. doi: 10.1038/oncsis.2016.17

Benelli, R., Vene, R., Ciarlo, M., Carlone, S., Barbieri, O., and Ferrari, N. (2012). The AKT/NF-kappaB inhibitor xanthohumol is a potent anti-lymphocytic leukemia drug overcoming chemoresistance and cell infiltration. Biochem. Pharmacol. 83, 1634-1642. doi: 10.1016/j.bcp.2012.03.006

Cao, J., Zhu, X., Zhao, X., Li, X. F., and Xu, R. (2016). Neutrophil-to-lymphocyte ratio predicts PSA response and prognosis in prostate cancer: a systematic review and meta-analysis. PLoS One 11:e0158770. doi: 10.1371/journal.pone. 0158770

Chen, L., Qiu, Y., Hao, Z., Cai, J., Zhang, S., Liu, Y., et al. (2017). A novel humanized anti-tumor necrosis factor-related apoptosis-inducing ligand-R2 monoclonal antibody induces apoptotic and autophagic cell death. IUBMB Life 69, 735-744. doi: 10.1002/iub.1659

Chen, P. H., Chang, C. K., Shih, C. M., Cheng, C. H., Lin, C. W., Lee, C. C., et al. (2016). The miR-204-3p-targeted IGFBP2 pathway is involved in xanthohumol-induced glioma cell apoptotic death. Neuropharmacology 110, 362-375. doi: 10.1016/j.neuropharm.2016.07.038

Chen, Q., Wang, L., Ma, Y., Wu, X., Jin, L., and Yu, F. (2014). Increased hepcidin expression in non-small cell lung cancer tissue and serum is associated with clinical stage. Thorac. Cancer 5, 14-24. doi: 10.1111/1759-7714.12046

Chen, Q. H., Fu, M. L., Chen, M. M., Liu, J., Liu, X. J., He, G. Q., et al. (2012). Preparative isolation and purification of xanthohumol from hops (Humulus lupulus L.) by high-speed counter-current chromatography. Food Chem. 132, 619-623. doi: 10.1016/j.foodchem.2011.10.098

Colgate, E. C., Miranda, C. L., Stevens, J. F., Bray, T. M., and Ho, E. (2007). Xanthohumol, a prenylflavonoid derived from hops induces apoptosis and inhibits NF-kappaB activation in prostate epithelial cells. Cancer Lett. 246, 201-209. doi: 10.1016/j.canlet.2006.02.015

Cook, M. R., Luo, J., Ndiaye, M., Chen, H., and Kunnimalaiyaan, M. (2010). Xanthohumol inhibits the neuroendocrine transcription factor achaete-scute complex-like 1, suppresses proliferation, and induces phosphorylated ERK1/2 in medullary thyroid cancer. Am. J. Surg. 199, 315-318; discussion 318. doi: 10.1016/j.amjsurg.2009.08.034

Cosetti, M., Yu, G. P., and Schantz, S. P. (2008). Five-year survival rates and time trends of laryngeal cancer in the US population. Arch. Otolaryngol. Head Neck Surg. 134, 370-379. doi: 10.1001/archotol.134. 4.370

Cuvertino, S., Filiciotto, G., Masurekar, A., Saha, V., Lacaud, G., and Kouskoff, V. (2017). SOX7 promotes the maintenance and proliferation of B cell precursor acute lymphoblastic cells. Oncotarget 8, 64974-64983. doi: 10.18632/oncotarget. 10472

D’Cruz, A. K., Vaish, R., Vaidya, A., Nixon, I. J., Williams, M. D., Vander Poorten, V., et al. (2018). Molecular markers in well-differentiated thyroid cancer. Eur. Arch. Otorhinolaryngol. doi: 10.1007/s00405-018-4944-1 [Epub ahead of print].

Deeb, D., Gao, X., Jiang, H., Arbab, A. S., Dulchavsky, S. A., and Gautam, S. C. (2010). Growth inhibitory and apoptosis-inducing effects of xanthohumol, a prenylated chalone present in hops, in human prostate cancer cells. Anticancer Res. 30, 3333-3339.

Dokduang, H., Yongvanit, P., Namwat, N., Pairojkul, C., Sangkhamanon, S., Yageta, M. S., et al. (2016). Xanthohumol inhibits STAT3 activation pathway leading to growth suppression and apoptosis induction in human cholangiocarcinoma cells. Oncol. Rep. 35, 2065-2072. doi: 10.3892/or.2016. 4584

Dorn, C., Weiss, T. S., Heilmann, J., and Hellerbrand, C. (2010). Xanthohumol, a prenylated chalcone derived from hops, inhibits proliferation, migration and interleukin-8 expression of hepatocellular carcinoma cells. Int. J. Oncol. 36, 435-441. doi: 10.1055/s-0029-1246396

Dostalek, P., Karabin, M., and Jelinek, L. (2017). Hop phytochemicals and their potential role in metabolic syndrome prevention and therapy. Molecules 22:E1761. doi: 10.3390/molecules22101761

Drenzek, J. G., Seiler, N. L., Jaskula-Sztul, R., Rausch, M. M., and Rose, S. L. (2011). Xanthohumol decreases Notch1 expression and cell growth by cell cycle arrest and induction of apoptosis in epithelial ovarian cancer cell lines. Gynecol. Oncol. 122, 396-401. doi: 10.1016/j.ygyno.2011.04.027

Dresel, M., Dunkel, A., and Hofmann, T. (2015). Sensomics analysis of key bitter compounds in the hard resin of hops (Humulus lupulus L.) and their contribution to the bitter profile of Pilsner-type beer. J. Agric. Food Chem. 63, 3402-3418. doi: 10.1021/acs.jafc.5b00239

Du, G. J., Zhang, Z., Wen, X. D., Yu, C., Calway, T., Yuan, C. S., et al. (2012). Epigallocatechin gallate (EGCG) is the most effective cancer chemopreventive polyphenol in green tea. Nutrients 4, 1679-1691. doi: 10.3390/nu4111679

Ellinwood, D. C., El-Mansy, M. F., Plagmann, L. S., Stevens, J. F., Maier, C. S., Gombart, A. F., et al. (2017). Total synthesis of $\left[{ }^{13} \mathrm{C}\right]_{2}-,\left[{ }^{13} \mathrm{C}\right]_{3}-$, and $\left[{ }^{13}\right.$ $\mathrm{C}_{5}$-isotopomers of xanthohumol, the principal prenylflavonoid from hops. J. Labelled Comp. Radiopharm. 60, 639-648. doi: 10.1002/jlcr.3571

Festa, M., Capasso, A., D'acunto, C. W., Masullo, M., Rossi, A. G., Pizza, C., et al. (2011). Xanthohumol induces apoptosis in human malignant glioblastoma cells by increasing reactive oxygen species and activating MAPK pathways. J. Nat. Prod. 74, 2505-2513. doi: 10.1021/np200390x

Fu, Y., Li, S., Zu, Y., Yang, G., Yang, Z., Luo, M., et al. (2009). Medicinal chemistry of paclitaxel and its analogues. Curr. Med. Chem. 16, 3966-3985. doi: 10.2174/ 092986709789352277

Gokduman, K. (2016). Strategies targeting DNA topoisomerase I in cancer chemotherapy: camptothecins, nanocarriers for camptothecins, organic noncamptothecin compounds and metal complexes. Curr. Drug Targets 17, 19281939. doi: 10.2174/1389450117666160502151707

Gueritte, F. (2001). General and recent aspects of the chemistry and structureactivity relationships of taxoids. Curr. Pharm. Des. 7, 1229-1249. doi: 10.2174/ 1381612013397429

Guerreiro, S., Monteiro, R., Martins, M. J., Calhau, C., Azevedo, I., and Soares, R. (2007). Distinct modulation of alkaline phosphatase isoenzymes by 17betaestradiol and xanthohumol in breast cancer MCF-7 cells. Clin. Biochem. 40, 268-273. doi: 10.1016/j.clinbiochem.2006.09.012

Gulei, D., Mehterov, N., Nabavi, S. M., Atanasov, A. G., and Berindan-Neagoe, I. (2017). Targeting ncRNAs by plant secondary metabolites: the ncRNAs game in the balance towards malignancy inhibition. Biotechnol. Adv. doi: 10.1016/j. biotechadv.2017.11.003 [Epub ahead of print].

Harikumar, K. B., Kunnumakkara, A. B., Ahn, K. S., Anand, P., Krishnan, S., Guha, S., et al. (2009). Modification of the cysteine residues in IkappaBalpha kinase and NF-kappaB (p65) by xanthohumol leads to suppression of NF-kappaB-regulated gene products and potentiation of apoptosis in leukemia cells. Blood 113, 2003-2013. doi: 10.1182/blood-2008-04151944

Hearing, V. J., and Jimenez, M. (1987). Mammalian tyrosinase-the critical regulatory control point in melanocyte pigmentation. Int. J. Biochem. 19, 1141-1147. doi: 10.1016/0020-711X(87)90095-4

Ho, Y. C., Liu, C. H., Chen, C. N., Duan, K. J., and Lin, M. T. (2008). Inhibitory effects of xanthohumol from hops (Humulus lupulus L.) on human hepatocellular carcinoma cell lines. Phytother. Res. 22, 1465-1468. doi: 10.1002/ ptr. 2481

Hussong, R., Frank, N., Knauft, J., Ittrich, C., Owen, R., Becker, H., et al. (2005). A safety study of oral xanthohumol administration and its influence on fertility in Sprague Dawley rats. Mol. Nutr. Food Res. 49, 861-867. doi: 10.1002/mnfr. 200500089

Jiang, W., Zhao, S., Xu, L., Lu, Y., Lu, Z., Chen, C., et al. (2015). The inhibitory effects of xanthohumol, a prenylated chalcone derived from hops, on cell growth and tumorigenesis in human pancreatic cancer. Biomed. Pharmacother. 73, 40-47. doi: 10.1016/j.biopha.2015.05.020 
Jitariu, A. A., Cimpean, A. M., Ribatti, D., and Raica, M. (2017). Triple negative breast cancer: the kiss of death. Oncotarget 8, 46652-46662. doi: 10.18632/ oncotarget.16938

Kang, Y., Park, M. A., Heo, S. W., Park, S. Y., Kang, K. W., Park, P. H., et al. (2013). The radio-sensitizing effect of xanthohumol is mediated by STAT3 and EGFR suppression in doxorubicin-resistant MCF-7 human breast cancer cells. Biochim. Biophys. Acta 1830, 2638-2648. doi: 10.1016/j.bbagen.2012. 12.005

Kelloff, G. J., Boone, C. W., Crowell, J. A., Steele, V. E., Lubet, R., and Sigman, C. C. (1994). Chemopreventive drug development: perspectives and progress. Cancer Epidemiol. Biomarkers Prev. 3, 85-98.

Khupse, R. S., and Erhardt, P. W. (2007). Total synthesis of xanthohumol. J. Nat. Prod. 70, 1507-1509. doi: 10.1021/np070158y

Kim, S. Y., Lee, I. S., and Moon, A. (2013). 2-Hydroxychalcone and xanthohumol inhibit invasion of triple negative breast cancer cells. Chem. Biol. Interact. 203, 565-572. doi: 10.1016/j.cbi.2013.03.012

Klosek, M., Mertas, A., Krol, W., Jaworska, D., Szymszal, J., and Szliszka, E. (2016). Tumor necrosis factor-related apoptosis-inducing ligand-induced apoptosis in prostate cancer cells after treatment with xanthohumol-A natural compound present in Humulus lupulus L. Int. J. Mol. Sci. 17:E837. doi: 10.3390/ ijms 17060837

Koo, J. H., Kim, H. T., Yoon, H. Y., Kwon, K. B., Choi, I. W., Jung, S. H., et al. (2008). Effect of xanthohumol on melanogenesis in B16 melanoma cells. Exp. Mol. Med. 40, 313-319. doi: 10.3858/emm.2008.40.3.313

Kunnimalaiyaan, S., Sokolowski, K. M., Balamurugan, M., Gamblin, T. C., and Kunnimalaiyaan, M. (2015a). Xanthohumol inhibits Notch signaling and induces apoptosis in hepatocellular carcinoma. PLoS One 10:e0127464. doi: 10.1371/journal.pone.0127464

Kunnimalaiyaan, S., Trevino, J., Tsai, S., Gamblin, T. C., and Kunnimalaiyaan, M. (2015b). Xanthohumol-mediated suppression of Notch1 signaling is associated with antitumor activity in human pancreatic cancer cells. Mol. Cancer Ther. 14, 1395-1403. doi: 10.1158/1535-7163.MCT-14-0915

Kuribayashi, K., Funaguchi, N., and Nakano, T. (2016). Chemotherapy for advanced non-small cell lung cancer with a focus on squamous cell carcinoma. J. Cancer Res. Ther. 12, 528-534. doi: 10.4103/0973-1482.174185

LeComte, M. D., and Spees, J. L. (2016). Notch1-STAT3-ETBR signaling in brain injury and cancer. Cytokine 80, 64-65. doi: 10.1016/j.cyto.2015.08.259

Lee, E. S., Ko, K. K., Joe, Y. A., Kang, S. G., and Hong, Y. K. (2011). Inhibition of STAT3 reverses drug resistance acquired in temozolomide-resistant human glioma cells. Oncol. Lett. 2, 115-121. doi: 10.3892/ol.2010.210

Lee, S. H., Kim, H. J., Lee, J. S., Lee, I. S., and Kang, B. Y. (2007). Inhibition of topoisomerase i activity and efflux drug transporters' expression by xanthohumol. from hops. Arch. Pharm. Res. 30, 1435-1439.

Li, Y., Wang, K., Yin, S., Zheng, H., and Min, D. (2016). Xanthohumol inhibits proliferation of laryngeal squamous cell carcinoma. Oncol. Lett. 12, 5289-5294. doi: 10.3892/ol.2016.5313

Liu, B. L., Zhang, X., Zhang, W., and Zhen, H. N. (2007). New enlightenment of French Paradox: resveratrol's potential for cancer chemoprevention and anti-cancer therapy. Cancer Biol. Ther. 6, 1833-1836. doi: 10.4161/cbt.6.12. 5161

Liu, M., Hansen, P. E., Wang, G., Qiu, L., Dong, J., Yin, H., et al. (2015). Pharmacological profile of xanthohumol, a prenylated flavonoid from hops (Humulus lupulus). Molecules 20, 754-779. doi: 10.3390/molecules20010754

Liu, M., Yin, H., Qian, X., Dong, J., Qian, Z., and Miao, J. (2016). Xanthohumol, a prenylated chalcone from hops, inhibits the viability and stemness of doxorubicin-resistant MCF-7/ADR Cells. Molecules 22:E36. doi: 10.3390/ molecules 22010036

Liu, T., Li, Z., Zhang, Q., De Amorim Bernstein, K., Lozano-Calderon, S., Choy, E., et al. (2016). Targeting ABCB1 (MDR1) in multi-drug resistant osteosarcoma cells using the CRISPR-Cas9 system to reverse drug resistance. Oncotarget 7 , 83502-83513. doi: 10.18632/oncotarget.13148

Magalhães, P. J., Dostalek, P., Cruz, J. M., Guido, L. F., and Barros, A.A. (2008). The impact of a xanthohumol-enriched hop product on the behavior of xanthohumol and isoxanthohumol in pale and dark beers: a pilot scale approach. J. Inst. Brew. 114, 246-256. doi: 10.1002/j.2050-0416.2008.tb00335.x

Marquina, G., Manzano, A., and Casado, A. (2018). Targeted agents in cervical cancer: beyond bevacizumab. Curr. Oncol. Rep. 20:40. doi: 10.1007/s11912-0180680-3
McAdam, E. L., Freeman, J. S., Whittock, S. P., Buck, E. J., Jakse, J., Cerenak, A., et al. (2013). Quantitative trait loci in hop (Humulus lupulus L.) reveal complex genetic architecture underlying variation in sex, yield and cone chemistry. BMC Genomics 14:360. doi: 10.1186/1471-2164-14-360

Miranda, C. L., Stevens, J. F., Helmrich, A., Henderson, M. C., Rodriguez, R. J., Yang, Y. H., et al. (1999). Antiproliferative and cytotoxic effects of prenylated flavonoids from hops (Humulus lupulus) in human cancer cell lines. Food Chem. Toxicol. 37, 271-285. doi: 10.1016/S0278-6915(99)00019-8

Monteghirfo, S., Tosetti, F., Ambrosini, C., Stigliani, S., Pozzi, S., Frassoni, F., et al. (2008). Antileukemia effects of xanthohumol in Bcr/Abl-transformed cells involve nuclear factor-kappaB and p53 modulation. Mol. Cancer Ther. 7, 2692-2702. doi: 10.1158/1535-7163.MCT-08-0132

Monteiro, R., Calhau, C., Silva, A. O., Pinheiro-Silva, S., Guerreiro, S., Gartner, F., et al. (2008). Xanthohumol inhibits inflammatory factor production and angiogenesis in breast cancer xenografts. J. Cell. Biochem. 104, 1699-1707. doi: $10.1002 /$ jcb. 21738

Musella, A., Bardhi, E., Marchetti, C., Vertechy, L., Santangelo, G., Sassu, C., et al. (2018). Rucaparib: an emerging parp inhibitor for treatment of recurrent ovarian cancer. Cancer Treat. Rev. 66, 7-14. doi: 10.1016/j.ctrv.2018.03.004

Nikolic, D., and van Breemen, R. B. (2013). Analytical methods for quantitation of prenylated flavonoids from hops. Curr. Anal. Chem. 9, 71-85. doi: 10.2174/ 157341113804486554

Nookandeh, A., Frank, N., Steiner, F., Ellinger, R., Schneider, B., Gerhauser, C., et al. (2004). Xanthohumol metabolites in faeces of rats. Phytochemistry 65, 561-570. doi: $10.1016 /$ j.phytochem.2003.11.016

Ouban, A. (2018). Claudin-1 role in colon cancer: an update and a review. Histol. Histopathol. doi: 10.14670/HH-11-980 [Epub ahead of print].

Ouyang, G., Liu, Z., Huang, S., Li, Q., Xiong, L., Miao, X., et al. (2016). Gemcitabine plus cisplatin versus gemcitabine alone in the treatment of pancreatic cancer: a meta-analysis. World J. Surg. Oncol. 14:59. doi: 10.1186/s12957-0160813-9

Pan, J., Shen, J., Si, W., Du, C., Chen, D., Xu, L., et al. (2017). Resveratrol promotes MICA/B expression and natural killer cell lysis of breast cancer cells by suppressing c-Myc/miR-17 pathway. Oncotarget 8, 65743-65758. doi: 10.18632/oncotarget.19445

Pan, L., Becker, H., and Gerhäuser, C. (2005). Xanthohumol induces apoptosis in cultured 40-16 human colon cancer cells by activation of the death receptorand mitochondrial pathway. Mol. Nutr. Food Res. 49, 837-843. doi: 10.1002/ mnfr.200500065

Pang, Y., Nikolic, D., Zhu, D., Chadwick, L. R., Pauli, G. F., Farnsworth, N. R. et al. (2007). Binding of the hop (Humulus lupulus L.) chalcone xanthohumol to cytosolic proteins in Caco-2 intestinal epithelial cells. Mol. Nutr. Food Res. 51, 872-879. doi: 10.1002/mnfr.200600252

Plazar, J., Zegura, B., Lah, T. T., and Filipic, M. (2007). Protective effects of xanthohumol against the genotoxicity of benzo(a)pyrene ( $\mathrm{BaP}), 2$-amino-3methylimidazo[4,5-f] quinoline (IQ) and tert-butyl hydroperoxide (t-BOOH) in HepG2 human hepatoma cells. Mutat. Res. 632, 1-8. doi: 10.1016/j.mrgentox. 2007.03.013

Radovic, B., Schmutzler, C., and Kohrle, J. (2005). Xanthohumol stimulates iodide uptake in rat thyroid-derived FRTL-5 cells. Mol. Nutr. Food Res. 49, 832-836. doi: 10.1002/mnfr.200500053

Reitman, Z. J., Winkler, F., and Elia, A. E. H. (2018). New directions in the treatment of glioblastoma. Semin. Neurol. 38, 50-61. doi: 10.1055/s-00381623534

Rizvi, S., and Gores, G. J. (2013). Pathogenesis, diagnosis, and management of cholangiocarcinoma. Gastroenterology 145, 1215-1229. doi: 10.1053/j.gastro. 2013.10.013

Rodriguez-Casado, A. (2016). The health potential of fruits and vegetables phytochemicals: notable examples. Crit. Rev. Food Sci. Nutr. 56, 1097-1107. doi: 10.1080/10408398.2012.755149

Rossi, T., Gallo, C., Bassani, B., Canali, S., Albini, A., and Bruno, A. (2014). Drink your prevention: beverages with cancer preventive phytochemicals. Pol. Arch. Med. Wewn. 124, 713-722. doi: 10.20452/pamw.2560

Schramm, L. (2013). Going green: the role of the green tea component EGCG in chemoprevention. J. Carcinog. Mutagen. 4:1000142. doi: 10.4172/2157-2518. 1000142

Siegel, R. L., Miller, K. D., and Jemal, A. (2017). Cancer statistics, 2017. CA Cancer J. Clin. 67, 7-30. doi: 10.3322/caac. 21387 
Singh, P. K., and Silakari, O. (2017). Chemotherapeutics-resistance "arms" race: an update on mechanisms involved in resistance limiting EGFR inhibitors in lung cancer. Life Sci. 186, 25-32. doi: 10.1016/j.lfs.2017.08.001

Slawinska-Brych, A., Krol, S. K., Dmoszynska-Graniczka, M., Zdzisinska, B., Stepulak, A., and Gagos, M. (2015). Xanthohumol inhibits cell cycle progression and proliferation of larynx cancer cells in vitro. Chem. Biol. Interact. 240, 110-118. doi: 10.1016/j.cbi.2015.08.008

Slawinska-Brych, A., Zdzisinska, B., Dmoszynska-Graniczka, M., Jeleniewicz, W., Kurzepa, J., Gagos, M., et al. (2016). Xanthohumol inhibits the extracellular signal regulated kinase (ERK) signalling pathway and suppresses cell growth of lung adenocarcinoma cells. Toxicology 357-358, 65-73. doi: 10.1016/j.tox.2016. 06.008

Sporn, M. B., and Suh, N. (2002). Chemoprevention: an essential approach to controlling cancer. Nat. Rev. Cancer 2, 537-543. doi: 10.1038/nrc844

Stevens, J. F., Taylor, A. W., and Deinzer, M. L. (1999). Quantitative analysis of xanthohumol and related prenylflavonoids in hops and beer by liquid chromatography-tandem mass spectrometry. J. Chromatogr. A 832, 97-107. doi: 10.1016/S0021-9673(98)01001-2

Thein, H. H., Qiao, Y., Zaheen, A., Jembere, N., Sapisochin, G., Chan, K. K. W., et al. (2017). Cost-effectiveness analysis of treatment with non-curative or palliative intent for hepatocellular carcinoma in the real-world setting. PLoS One 12:e0185198. doi: 10.1371/journal.pone.0185198

Vakana, E., and Platanias, L. C. (2011). AMPK in BCR-ABL expressing leukemias. Regulatory effects and therapeutic implications. Oncotarget 2, $1322-1328$.

Vanhoecke, B. W., Delporte, F., Van Braeckel, E., Heyerick, A., Depypere, H. T., Nuytinck, M., et al. (2005). A safety study of oral tangeretin and xanthohumol administration to laboratory mice. In Vivo 19, 103-107.

Vene, R., Benelli, R., Minghelli, S., Astigiano, S., Tosetti, F., and Ferrari, N. (2012). Xanthohumol impairs human prostate cancer cell growth and invasion and diminishes the incidence and progression of advanced tumors in TRAMP mice. Mol. Med. 18, 1292-1302. doi: 10.2119/molmed.2012.00174

Venturelli, S., Burkard, M., Biendl, M., Lauer, U. M., Frank, J., and Busch, C. (2016). Prenylated chalcones and flavonoids for the prevention and treatment of cancer. Nutrition 32, 1171-1178. doi: 10.1016/j.nut.2016.03.020

Verzele, M., Stockx, J., Fontijn, F., and Anteunis, M. (1957). Xanthohumol, a new natural chalkone. Bull. Soc. Chim. Belg. 66, 452-475. doi: 10.1002/bscb. 19570660137

Wada, N., Fujisaki, M., Ishii, S., Ikeda, T., and Kitajima, M. (2001). Evaluation of bone metabolic markers in breast cancer with bone metastasis. Breast Cancer 8, 131-137. doi: 10.1007/BF02967492

Wang, Y., Yi, J., He, J., Chen, G., Li, L., Yang, Y., et al. (2014). Cognitive emotion regulation strategies as predictors of depressive symptoms in women newly diagnosed with breast cancer. Psychooncology 23, 93-99. doi: 10.1002/pon.3376

Wangyang, Z., Daolin, J., Yi, X., Zhenglong, L., Lining, H., Yunfu, C., et al. (2018). NcRNAs and cholangiocarcinoma. J. Cancer 9, 100-107. doi: 10.7150/jca.21785

Weidle, U. H., Birzele, F., Kollmorgen, G., and Rueger, R. (2016). Mechanisms and targets involved in dissemination of ovarian cancer. Cancer Genomics Proteomics 13, 407-423. doi: 10.21873/cgp.20004

Wesolowska, O., Gasiorowska, J., Petrus, J., Czarnik-Matusewicz, B., and Michalak, K. (2014). Interaction of prenylated chalcones and flavanones from common hop with phosphatidylcholine model membranes. Biochim. Biophys. Acta 1838, 173-184. doi: 10.1016/j.bbamem.2013.09.009
Wu, J. C., Lai, C. S., Tsai, M. L., Ho, C. T., Wang, Y. J., and Pan, M. H. (2017). Chemopreventive effect of natural dietary compounds on xenobioticinduced toxicity. J. Food Drug Anal. 25, 176-186. doi: 10.1016/j.jfda.2016. 10.019

Xie, C., Lu, Z., Liu, G., Fang, Y., Liu, J., Huang, Z., et al. (2015). Numb downregulation suppresses cell growth and is associated with a poor prognosis of human hepatocellular carcinoma. Int. J. Mol. Med. 36, 653-660. doi: 10.3892/ ijmm.2015.2279

Yang, X., and Lin, D. (2016). Changes of 2015 WHO histological classification of lung cancer and the clinical significance. Zhongguo Fei Ai Za Zhi 19, 332-336. doi: 10.3779/j.issn.1009-3419.2016.06.06

Yong, W. K., and Abd Malek, S. N. (2015). Xanthohumol induces growth inhibition and apoptosis in ca ski human cervical cancer cells. Evid. Based Complement. Alternat. Med. 2015:921306. doi: 10.1155/2015/921306

Yong, W. K., Ho, Y. F., and Malek, S. N. (2015). Xanthohumol induces apoptosis and $\mathrm{S}$ phase cell cycle arrest in A549 non-small cell lung cancer cells. Pharmacogn. Mag. 11, S275-S283. doi: 10.4103/0973-1296. 166069

Yoo, Y. B., Park, K. S., Kim, J. B., Kang, H. J., Yang, J. H., Lee, E. K., et al. (2014). Xanthohumol inhibits cellular proliferation in a breast cancer cell line (MDA-MB231) through an intrinsic mitochondrial-dependent pathway. Indian J. Cancer 51, 518-523. doi: 10.4103/0019-509X.175328

Zanoli, P., and Zavatti, M. (2008). Pharmacognostic and pharmacological profile of Humulus lupulus L. J. Ethnopharmacol. 116, 383-396. doi: 10.1016/j.jep.2008. 01.011

Zhang, B., Chu, W., Wei, P., Liu, Y., and Wei, T. (2015). Xanthohumol induces generation of reactive oxygen species and triggers apoptosis through inhibition of mitochondrial electron transfer chain complex I. Free Radic. Biol. Med. 89, 486-497. doi: 10.1016/j.freeradbiomed.2015.09.021

Zhang, P., Li, H., Yang, B., Yang, F., Zhang, L. L., Kong, Q. Y., et al. (2014). Biological significance and therapeutic implication of resveratrol-inhibited Wnt, Notch and STAT3 signaling in cervical cancer cells. Genes Cancer 5, 154-164.

Zhao, H., Xie, P., Li, X., Zhu, W., Sun, X., Sun, X., et al. (2015). A prospective phase II trial of EGCG in treatment of acute radiation-induced esophagitis for stage III lung cancer. Radiother. Oncol. 114, 351-356. doi: 10.1016/j.radonc.2015. 02.014

Zhao, H., Zhu, W., Jia, L., Sun, X., Chen, G., Zhao, X., et al. (2016). Phase I study of topical epigallocatechin-3-gallate (EGCG) in patients with breast cancer receiving adjuvant radiotherapy. Br. J. Radiol. 89:20150665. doi: 10.1259/bjr. 20150665

Conflict of Interest Statement: The authors declare that the research was conducted in the absence of any commercial or financial relationships that could be construed as a potential conflict of interest.

Copyright (c) 2018 Jiang, Sun, Xiang, Wei and Li. This is an open-access article distributed under the terms of the Creative Commons Attribution License (CC BY). The use, distribution or reproduction in other forums is permitted, provided the original author(s) and the copyright owner are credited and that the original publication in this journal is cited, in accordance with accepted academic practice. No use, distribution or reproduction is permitted which does not comply with these terms. 